FILIP GALOVIĆ

\title{
O LEKSIKU SVETOJURSKOGA GOVORA
}

Filip Galović

Hrvatsko katoličko sveučilište

Ilica 242

HR 10000 Zagreb

filip.galovic@unicath.hr
UDK: 81’374.2:81’28(497.5Sv.Juraj)

Izvorni znanstveni članak

11.11.2019.

Govor je Svetoga Jurja štokavski govor te pripada zapadnomu dijalektu, kao i svi govori podvelebitskoga područja, osim čakavskoga govora grada Senja. Senjski je govor, kao govor administrativnoga i kulturnoga središta ovoga prostora, izvršio stanovit utjecaj na svetojurski govor, pa i danas u njemu žive pojedini čakavski nanosi. U radu se iznose najvažnije fonološke i morfološke značajke govora Svetoga Jurja te se posebno osvrće na leksik ovoga štokavskoga govora.

Ključne riječi: Sveti Juraj, dijalektološke značajke, leksik, novoštokavski ikavski dijalekt, štokavsko narječje

\section{Uvod}

Sveti se Juraj smjestio podno Velebita, desetak kilometara južno od grada Senja, uz Jadransku magistralu. To tipično primorsko naselje, prema podatcima Državnoga zavoda za statistiku iz 2011. godine, ima 600-ak stanovnika.

Dobro je poznato da cijeli podvelebitski prostor pripada štokavskomu narječju, njegovu novoštokavskomu ikavskomu dijalektu, izuzev čakavskoga govora Senja. Premda nema objavljenih detaljnijih podataka o ovome govoru, njegove se bitne dijalektološke značajke saznaju iz članka Milana Moguša Pogled na današnji jurjevački govor iz 1978. godine. Tu je Moguš zaključio da je svetojurski govor "jedan primorski štokavski ikavski govor s novijom akcentuacijom, govor koji je bio i koji jest zbog svoga položaja pod vrlo jakim utjecajem čakavskoga Senja"1. Senjski je čakavski nanos i danas u pojedinim crtama očigledan.

\footnotetext{
${ }^{1}$ M. MOGUŠ, 1975, 232.
} 


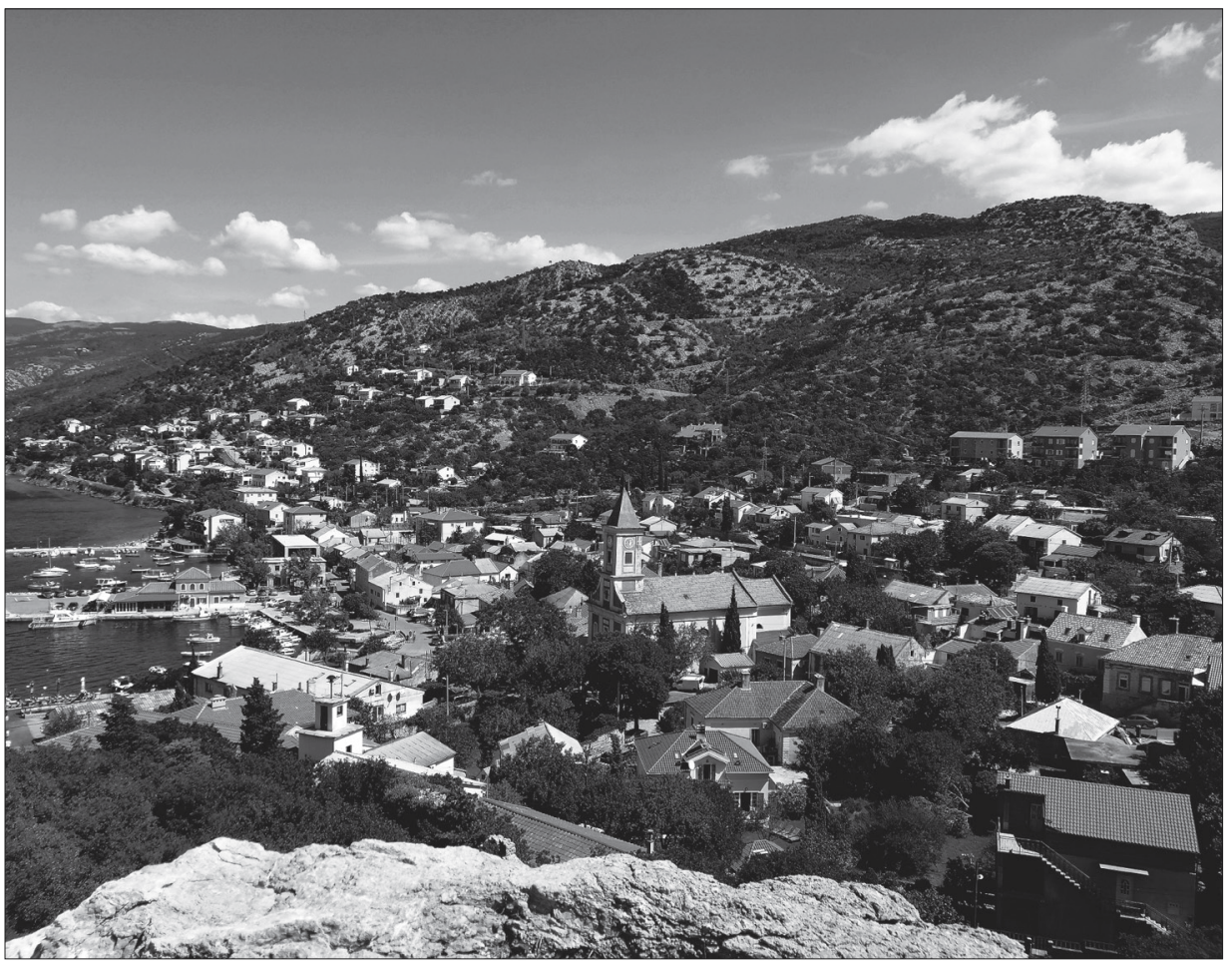

S1.1. Naselje Sveti Juraj (foto: Filip Galović)

U kolovozu sam 2019. godine nekoliko dana boravio u senjskome kraju te sam se osobito bavio istraživanjem govora Svetoga Jurja. ${ }^{2}$ Dijalektološku sam građu prikupio metodom slobodnoga, nevezanoga razgovora, ali i na temelju posebno koncipiranoga kvestionara. Mojim su konzultantima bili: Vesna Babić (1943.), Ivan Samaržija (1953.) i Ivan Rukavina (1960.). Neke sam zanimljive podatke saznao od mladoga i zainteresiranoga Bruna Vrbana (1993.). ${ }^{3}$ Osim navedenih, razgovarao sam i s pojedinim drugim mještanima te pomno osluškivao govor na rivi i u lokalnoj gostionici. Na temelju sam prikupljenoga materijala detaljnije pisao o fonologiji i morfologiji ovoga govora u zasebnome

${ }^{2}$ Za pripomoć u nalaženju govornika osobito zahvaljujem Blaženki Ljubović iz Gradskoga muzeja Senj i župniku Svetoga Jurja don Silviju Milinu. Ističem i Bruna Vrbana koji me također zdušno usmjerio na pojedine.

${ }^{3}$ Svi su konzultanti bili upoznati s činjenicom da je riječ o terenskome dijalektološkome istraživanju te su svojevoljno iznijeli podatke o sebi i dopustili snimanje/zapisivanje govorenoga materijala. 
članku. ${ }^{4} \mathrm{~S}$ obzirom na to da se i leksička razina ukazala zanimljivom, ovdje se, pored najbitnijih fonoloških i morfoloških podataka, osvrće na osobitosti u leksiku svetojurskoga govora.

\section{Osnovne fonološke i morfološke crte}

Govor je Svetoga Jurja u načelu ikavski: grijòta, sikira, svit, dica, podílit, lètili, živili, mïsec, s nekoliko poznatih ekavskih likova koji su obični među novoštokavcima ikavcima, npr. zènica, zanovétat, öbe i sl. Međutim, u svetojurskome se govoru nalaze i neki drugi ekavizmi koji su nanos iz senjskoga govora: cêli, sréda, kòleno, lëto, mësto, òbed, zvézda i niz drugih. Stara je zamjena samoglasnikom $a$ vidljiva u jädro i prama.

Nekadanji su poluglasovi rezultirali samoglasnikom a: màgla, òtac, päs, döbar. Tipična je čakavska značajka tzv. 'jake vokalnosti' potvrđena u nekoliko riječi: mälin, mäša, mäšit. Ovamo idu i oblici välje (pored ödma) i väjk (pored üvik), dakle s čakavskim razvojem $v a$, inače je uobičajeno $u$ : ùnūtra, ùnuk, Ùskrs, ùzêt, ùžgat, u sèlu. Usamljene su ovjere šënac ('uš') i čêra (pored jùčè(r)).

Nazalni je samoglasnik prednjega reda *e, kako se očekuje u štokavskim govorima, izjednačen s etimološkim $e$ u svim položajima i primjerima: gòvedina, mêso, tïme, jèzik, jétra, pòcêt, nàčèt, žët. Izolirani je nalaz glagol prìjat ('primiti') $\mathrm{s}$ rezultatom $a$ kao u mnogih čakavaca.

$\mathrm{Na}$ mjestu je nekadanjega slogotvornoga $l$ i nazalnoga samoglasnika stražnjega reda $*_{Q}$ očekivano nastupio samoglasnik $u$ : jäbuka, tûst; gölub, kùpina, grédu (3. mn. prez.).

Štokavsko-čakavski prijelaz sekvence $r a$ u re zahvatio je lekseme rébac i nàrēst, no nema izmjene u kräst.

Zamjena za štokavsko $d \check{z}$ jest glas ž: žëp, žĭgerica, svjedožba.

Glas je $d$ rezultat primarne i sekundarne jotacije dentala $* d$, a isti stoji $\mathrm{u}$ primljenih riječi, kao i u osnovi prezenta glagola prefigiranih s *iti: mläđi, prëđa, röđak, nadògrāđen, čäđa; đîr; dôđe, nâđete. Ovdje odstupa primjer göspoja, dakle s $j$.

Glasovi su se $\check{c}$ i $c$ sveli na jedan glas srednje tvrdoće: čìst, nôč ${ }^{5}$

Govor je šćakavski: pûščamo, ülišče, nätašče, prîšč ; gröžđe, mòžđani.

\footnotetext{
${ }^{4}$ Članak je pod nazivom Govor Svetoga Jurja (pored Senja) u listopadu 2019. godine predan uredništvu časopisa Croatica et Slavica Iadertina te je upućen u recenzentski postupak.

${ }^{5} \mathrm{U}$ cijelome se radu iz tehničkih razloga mjesto srednjega glasa bilježi $\check{c}$.
} 
Glas je $h$ zamuknuo: u ládu, ïljada, razládilo se, grî ('grijeh'), vr̈ ('vrh'), krü ('kruh'), ili je zamijenjen glasom v: bùva, üvo, glûv; ili j: mìjūr; ili $k$ : špàrket (i špàret).

Glas se $f$ dobro čuva, a pretežito dolazi u primljenica: fàžōl,jëftin, fijúkat, frïgat te na mjestu skupina *pv: ùfān se $\mathrm{i} * h v$ : fála, zafálit (ali ùvatit).

Glas $l$ biva zadržan na dočetku imenica, pridjeva i priloga: sôl, kòtāl, pàkāl, sökol; tëpal, vësel, bêl; òzdōl, kao i na dočetku unutarnjega sloga: télca, pâlca, žàlba. U pridjevu je radnome muškoga roda jednine izmijenjen u a: nòsija, vïdija, òbaša, pëka.

Mjesto $m$ u nastavcima i nepromjenjivim riječima nastupa $n: s$ mënon, lïtron, sèstran (DLI mn.), večìnōn, sëdan, ösan.

Skupina je $\check{c} r(<* \check{c} b r$, *čer) sustavno prometnuta u cr: crívo, cr̈n, cr̈v, zacrvènit se.

U posuđenica stoje skupine $\check{s} t, \breve{s} k, \breve{s} p(<s t, s k, s p)$ : broštùlīn, škabèlīn ('ladica'), špïca.

Osnova je $v_{s-}\left(<* v b s^{-}\right)$nakon redukcije poluglasa i provedene metateze izmijenjena u sv- : sväku, svï, svë, svèga.

Rotacizam je poznat i ovomu govoru: möreš, möremo premda cirkuliraju i likovi möžeš i möžemo. "Dolazi mörda."

Disimilacije se vrše u sedàvnājst, osàvnājst, gúvno, sùmljān, dîmljak i sl., a asimilacije su rijetke, pa se eventualno čuje čižme.

Naglasni se sustav sastoji od četiriju naglasaka (üžgala, plîsan, iscídit, tèlič), zanaglasne duljine i kračine. Akcentuacija je uglavnom novoštokavska. Zanaglasne se duljine većinom pokraćuju (päzin 1. jd. prez., mlädost, od stâre vüne). Naglasak može preskakati (pöd bokon, prïd oči) ili ne (od šrca, u šümi), a naglasak se može i prenositi (okò kuče, nà mašu).

$\mathrm{U}$ deklinaciji imenica treba spomenuti u instrumentalu jedinine nastavak -on bez obzira na palatalnost dočetnoga suglasnika osnove (nóžon). Kratke su množine dosta uobičajene (brödi, gölubi) premda se nađe i dugih množina (kräkovi). Genitiv množine danas često ima nastavak -i (mïši, krílì, óvcī), no u svim je rodovima živ i štokavski -a (pásāa, slóvā, sestárā). Dativ, lokativ i instrumental množine sviju rodova zahvatio je sinkretizam na -in, odnosno -an (läktin, sèlīn, süzan) premda su se uvukli i nastavci -ima te -ama (kònjima, kòlenima, rùkama).

U ličnih je zamjenica vrijedno istaknuti lik s mënon ('sa mnom'), dakle s osnovom men-, ali s druge strane čujemo töbon i söbon. U dativu, lokativu i instrumentalu ličnih zamjenice 'ja' i 'ti' ovjereno je nämi, vämi. Govori se kö, što, kàkī, (o)vàkī, nïki, nïšto, nïšta (uz nïš), itd. 
U genitivu se jednine muškoga i srednjega roda pridjevsko-zamjeničke deklinacije razlikuju nastavci -oga i -ega (slöbodnoga, mläđega), u dativu i lokativu -on i -en (stâron, mläđen).

Među brojevnim pridjevima treba podvući likove čëtvero, pëtero, naravno zbog morfa -er-.

Infinitivi su većinom krnji: naránit, gòrit, nâč.

Značajno je i to da je u infinitivima glagola II. vrste dominantan sufiks - $n u-$ : dïgnut, pomàknut, a u oblicima je tvorenih od infinitivne osnove evidentiran -ni-: krénila, zïnija.

U 3. su licu množine prezenta zabilježene različite mogućnosti: gòvoridu, nösidu, darivaju, mäžu, zòvū. Pored ovakvih se realizacija čuju i realizacije s -e: bòlē, sâde, zàtvore.

\section{Leksik}

\subsection{Leksički slojevi}

Posvema je jasno da svetojurski govor obiluje leksemima iz naslijeđenoga, slavenskoga leksičkoga fonda, npr.: crívo, dlän, büra, kûs ('komad'), rúbac, žûč, gòvedina i brojni drugi. Ovamo ide i imenica pöstelja, koja se i danas čuje, a stariji je narod nerijetko govorio i líglo. Osobito su vrijedni nalazi poput grémo, grédu 'ići', stari glagol poznat svima trima narječjima, jednako kao i iskat 'tražiti'. U Svetome se Jurju, kao kod nekih štokavaca i brojnih čakavaca, rabi riječ pôt ('znoj'). Zanimljiva je i imenica mêl koja pokriva značenje 'pijesak'. Dodajem ovdje da je zabilježen iskaz: äl su ti vlâsi tänke, gdje se susrećemo sa starom riječju koja se govori među čakavcima i kajkavcima te nekim štokavcima.

U govor se uvukao i znatan broj germanizama: šnâjder ('krojač'), špàret/ špàrket, klôfer ('isprašivač'), fâlda ('pregib, nabor (ob. na tkanini)'), brïktaš ('novčanik'), rôr ('pećnica'), mêlta ('žbuka'), mêrlin ('mrkva'), štrüca ('kruh izdužena oblika').

Govor zna i za neke orijentalizme kao što su benávit ('pričati gluposti'), bùbrig, jàran, žìgerica, žêp, čòban.

Očekivano cirkulira i stanovit broj leksema romanskoga postanja. U značenju se 'limena cijev (ob. za odvođenje dima)' rabi romanizam trûmba. Imenica bànkīna pokriva značenje 'kameni rub uz cestu'. Za 'brodsko skladište, tovarni prostor u brodu' govori se štîva. Glagol kòštat rabi se u značenju 'pristati (o brodu)'. Svetojurski se termin paràpet pojavljuje u značenju 'zidić, kamena ograda uz cestu'. Ima, naravno i drugih romanizama: cïma ('konop za vezivanje 
broda'), opitùrat ('obojiti, oličiti'), pörat ('luka'), prêza ('kameni ili željezni stup na obali za vezivanje broda'), nèvēra ('nevrijeme'), karnèvāl itd.

\subsection{Pojedine semantičke sfere}

Iz pojedinih se semantičkih sfera također mogu izdvojiti pojedini zanimljivi termini. Nazivi su za određene ribe: čifal ('cipal'), žäba ('grdobina'), šàmpjēr (rabi se i nazivak kòvāč), minčūn ('inćun'), škr̈poč, pöp ('fratar'), trïlja, palàmīda, göf, lòkārda, špâr, mïš ('sitna crna morska riba, crnej'), särāg/särag ('šarag'), ïgla, àrbūn, kämenica ('raža'), pïc, kânj ('kanjac'), vräna, lènica ('drozd'), knêz, mòdrālj ('modrak'), öliga, lòvrata ('orada'), zùbac, lüben ('brancin'), óvčica, grüg ('ugor'). Za 'hobotnicu' se kaže mr̈kāča. 'Lignja' glasi obično lïgnja, a 'lignjun' se naziva tôtanj.

Od ribarskoga se pribora često govori: üdica, östi, vřša, mrïža (pojedine su vrste primjerice: pöpona, grïp, sanàdīža i sl.), säk ('mrežasta vrećica na metalnome obruču s ručkom, janka'), palingāa ('parangal'), pöbuk ('predmet kojime se udara o površini mora kako bi se riba preplašila i otišla u mrežu'), fèrāl.

Uobičajeni su termini öseka i plíma, a vezano za vremenske pojave i vjetrove javljaju se riječi: nevèrīn, nëvēra/nèvēra, pùlenat, tremùntāna (čuje se i tremuntànez), lèbič, lèvānt, jügo, büra. Naziv fortùnāl označuje 'vrlo jak vjetar', pa se često kaže fortùnāl büre, fortùnāl jüga.

Iz terminologije se vezane za pojam kuće (dijelovi kuće, predmeti u kući, uređenje kuće) može izdvojiti: dvörišče, štêrna, kröv, tàvan, küpa ('crijep'), lîndra ('rub krova koji prelazi vanjski dio kuće'), žlîb ('limeni kanal kroz koji protječe kišnica'), gréda, vráta, pùneštra, fùmār/dìmljak, stôl, pöstelja (i líglo), kïnderbet ('dječji krevetac'), štràmac ('madrac') itd. U Svetome je Jurju škabèlìn 'ladica', a košùnel 'jastuk'. U nekim hrvatskim govorima čujemo krpatur u značenju 'vrsta pokrivača' dok se u Svetome Jurju govori krapàtūr. Spominjem i poznatu riječ biljac.

Posebno se mogu izdvojiti leksemi vezani za kuhinju (kuhinjski predmeti), za koju se u Svetome Jurju kaže küjina, dakle na štokavski način s mijenom $h>$ $j$. 'Željezni kotlić za kuhanje palente' naziva se pinjata. U značenju 'cjedilo za tijesto' narod govori pïnjenica. Značenje 'lijevak' pokriva tràtūr. Uobičajen je termin pijat 'tanjur', zatim žlïca i vïlica, čäša, fläša (pored böca), bòkāl. Govori se obično lònac. 'Posuda za jušna jela' ima naziv jûšnik. 'Limena posuda za pečenje mesa ili kruha' nosi naziv kàštrōla. Poznata imenica broštùlīn govori se i ovdje u značenju 'naprava za prženje kave, pržionik'. Germanizam rôr nosi 
značenje 'pećnica'. I u ovome se naselju govori dosta proširen termin gràdele. Osobito je važno istaknuti da ovdje čujemo kòpānj ('drvena naprava u kojoj se mijesio kruh', dakle u muškome rodu).

Od nazivlja je, koje se odnosi na jela, registrirano: bràžōla, bakàlār, têsto ('tjestenina'), riža, sâlsa ('umak od ukuhanih rajčica sa začinima'). Za 'ocat' se kaže òstika. Zasebno bi se mogle navesti slastice kojih nije velik broj. Za 'orahnjaču' dolazi termin örjevica. Značenje je 'vrsta okrugloga uštipka' pokrio termin frïta. U germanizme ide imenica köh koja se rabi(la) u značenju 'kolač od griza ili riže'.

Za neke se rodbinske odnose upotrebljavaju sljedeći termini: strîc (i striko i strikan), üjak, tétak, nëčak, nečàkinja, snája, púnac (i tâst), pünica. Uobičajeno se kaže röđak, a oni koji su u srodstvu kažu da su rôd, svôjta ili rödbina.

U nazive za ptice i domaću perad ulaze: mändel (i gäleb), rébac, vräna, slàvūj, lásta, sökol, gölub, kökoš, pívac, pülič (i püle).

Domaće životinje u Svetome Jurju imaju uglavnom uobičajene nazive: óvca, jänjac (i jänje), kòza, järac, jàrčič (i järe), vôl, kräva, tèličltélac, könj, kòbila, ždríbac ('mlado konja'), tòvar (i mágo), màgarica, püle ('mlado magare'), prâse, pràsica, päs, küja, mäčka.

Dobro je zabilježiti kako se pojedine životinje glasaju. Konj $\check{r z ̌ e}$, govedo mûče, ovca bléjī, koza mëkče, svinja rökče, pas läje, mačka mjàùče. Ptica gavran grâče.

Divlje su životinje rïs, mèdved, làsica, vûk i druge.

Termini su za povrće i voće: tïkvica, böb, sàlāta, zëlje ('kupus'), mêrlin ('mrkva'), blïtva, krästavac, kàpula, čèsan ('češnjak'), päprika, pomidōr, špināt, fàžôl, a za 'raštiku' se kaže râščc. Nadalje: jäbuka, armùlīn ('marelica'), òraj, mûrva, smökva, gröžđe, vïšnja, präska ('breskva'), rüšsa ('kruška'). Grm, odnosno nisko drvo ljekovitih plodova, dren, nosi naziv drinjula (ali i drènjula).

Od ljekovitih se biljaka češće koriste termini: stòlisnik, rüta, dùšica, smîlje, kàmilica. Biljke se koròmāč i úšac kuhaju i jedu kao zelje.

Među oruđima kojima se obavljaju poslovi na polju ili u vrtu jesu mòtika, gräblje, vïle. Dodajem da se kaže kòlac,u množini kôlci (kao potpora biljkama), a zbirna imenica glasi kôlje.

Leksemi iz sfere nošnje i oblačenja jesu: köšulja, vèštīd, òpānci, čǐžme, kïklja, frîz ('podsuknja'), žëp, fijok, büšt ('grudnjak'), jàketa, rúbac. Interesantno je da se za pregaču kaže záslon. Za hlače se danas najčešće kaže gäče, a stariji je narod govorio i läče. 'Donja majica' jest kontijêra ili kontijêrica. S unutrašnje je strane odjeće podstava koju narod naziva fûdra. 'Marama' je rúbac. Za dugme se kaže püca. Govori se kàiš i pöjas. 'Cipela' je pòstōl, dakle u muškome rodu. U 
modne dodatke, odnosno ukosnice idu šnála i špânga. U značenju se 'naušnica' obično govori rèčina.

Što se tiče pojedinih ljudskih osobina, za onu koja mnogo laže govori se làžljivica, a za muško čeljade làžac. Žensko čeljade koje često obilazi druge kuće (a uz to i uživa u govorenju i sl.) jest klátežica jer glagol klátit se nosi značenje 'skitati se'. Onaj koji često plače jest pláčko.

Vrijedno je istaknuti još poneke zanimljive lekseme $\mathrm{u}$ istraživanome govoru. Termin cvitak označava 'maramu uvijenu u krug koja se podmeće na glavu ispod tereta koji se nosi, podsvitak'. 'Ognojeno mjesto (ob. na tabanima)', odnosno oštećenje na koži koje je nastajalo uslijed hodanja bez obuće, naziva se nátučak. Značenje 'astma, zaduha' nosi poznat termin zâduva, ovdje s dugim silaznim naglaskom. Romanizam je flâjda ovjeren u značenju 'vrsta haljine na kopčanje (ob. crne boje) koju su običavale nositi starije žene'. Za prijevoz su se rasutoga tereta (najčešće pijeska) koristila nosila s ručkama koja se nazivaju tràgače (ž mn.). Teret se također prenosio ručnim kolicima s jednim kotačem, čiji je naziv karijōla.

\subsection{Leksemi u svetojurskome govoru i nekim drugim štokavskim govorima ${ }^{6}$}

U Svetome se Jurju kaže rébac, a jednako je tako u Ninu, Popovićima i Jasenicama. Lovinac ima vrébac. Na sinjskome je prostoru rebac i vrebac, a u Siveriću samo vrebac.

Zabilježeno je da Svetojurci govore fâlda u značenju 'pregib, nabor (ob. na tkanini)'. Ta se imenica javlja i na sinjskome području i u Siveriću, dok u Lovincu i u Jasenicama dolazi u varijanti vâlda. Naravno, fâlda ili fãlda govore brojni čakavci.

Među Svetojurcima se čuje fundàment i fundàmenat u značenju 'temelj'. U Siveriću se i na sinjskome prostoru govori fundament, u Ninu fundàmenat, u Lovincu i Popovićima vundàmenat, a u Jasenicama vundàmēnt.

Značenje je 'vrpca koja se veže na određen način' u Svetome Jurju pokrila imenica fijok. U Siveriću je i na sinjskome prostoru ovjereno fjok, dok u selu Popovići dolazi vijok.

\footnotetext{
${ }^{6}$ Većina se leksema iz svetojurskoga govora uspoređuje s bliskim i udaljenijim jezičnim sustavima, uglavnom štokavskima, veoma rijetko čakavskima. Podatci su iz štokavskoga Lovinca, Nina, Popovića, Jasenica, Siverića, sa sinjskoga područja te s čakavskoga Grobnika preuzeti iz objavljenih rječnika ili drugih studija, što je, razumije se, navedeno u popisu literature. Kako se u ovome dijelu tekst ne bi suviše optrećivao, ne navodi se određeni izvor.
} 
U opserviranome je govoru u značenju 'krojač' evidentiran germanizam šnâjder, kao primjerice i u Jasenicama. Zanimljivo je da na sinjskome području dolazi romanizam šaltur.

Prilog se 'uvijek' govori u liku väjk. U Lovincu se govori väjīk i väìk, u Ninu vävik, u Popovićima vǟ i vǟk, u Jasenicama vǟk, u Siveriću vaik, dok se na sinjskome prostoru čuje vaik i vavik, ali i romanizam šempre.

'Pčelinjak, ulište' u Svetome Jurju nosi naziv ülišče. U sinjskome su kraju registrirane varijante ulišće i ulište, a u Popovićima ülǐštelùlǐšte, u Lovincu ùlǐšte.

U Jasenicama i Lovincu dolazi džigerica, i u Siveriću je džigerica, na sinjskome prostoru džigerica. Svetojurci imaju ovdje $\check{z}$, poput čakavaca i nekih štokavaca, dakle žĭgerica.

U Svetome Jurju i Popovićima govore žèlezo, u Lovincu čujemo gvǒžđe, na sinjskome prostoru i u Siveriću gožđe. U Ninu se pak pedesetih godina čulo gòzje, no ne znamo kako je danas.

'Naprava za prženje kave, pržionik' nosi naziv broštùlīn. Bruštùlīn je ovjereno u Popovićima. U popisima riječi sinjskoga kraja i Siverića stoji bruštulin.

Sveti Juraj ima leksem grijòta, isto kao Popovići, Jasenice i Lovinac. Zabilježeno je grijota i u sinjskome kraju te u Siveriću.

Nekoć se u Svetome Jurju govorilo mejaš (Moguš 1978: 230), no i najstariji stanovnici sada govore mëđa. Mëđa/mèđa dolazi u Popovićima, a na sinjskome prostoru međa i mejaš. Stari je ninski govor nekoć imao mèja, no više nije tako.

Kako je već gore navedeno, Svetojurci kažu rođak. Glas đ dolazi i u róđo u Jasenicama. Popovići imaju rödijāk, sinjsko područje rodijak. Zanimljivo je stanje bilo pedesetih u Ninu gdje je registrirano rödjāk, ròdijāk i novije röđāk.

Zanimljivo je da se u Jasenicama i Popovićima leksem škabèlìn rabi u značenju 'ormarić', dok u Svetome Jurju isti dolazi u značenju 'ladica'. Značenje je kao u Svetome Jurju, primjerice, notirano na čakavskome Grobniku.

Značenje ‘željezni okov, šarka’ u Svetome Jurju nosi imenica kànjōla. U Lovincu je registriran muški rod, dakle kànjōl.

Spomenuto je da imenica bànkīna pokriva značenje 'kameni rub uz cestu', a isto je ovjereno u Jasenicama i Popovićima. I na sinjskome se području čuje bankina. Grobničani također kažu taj leksem, naravno s drugačijim akcentom: bānkîna.

Zanimljiv je općebalkanski pastirski termin bälega, koji nosi značenje 'izmet goveda', a nepoznatoga je postanja (Skok 1971-1974: 100). U sinjskome je kraju evidentirano balega/balegina i galeba/galebina. Lovinac i Popovići imaju gäleba. 
U značenju se 'okretan, hitar, spretan' govori romanizam žvëlt, jednako kao u Ninu, Jasenicama i Popovićima. I u Siveriću i na sinjskome području dolazi žvelt.

Sveti Juraj, Jasenice i Lovinac imaju leksem lúpež ('lopov'). Rječnik sinjskoga prostora ima također lupež.

Značenje 'madrac' zastupa termin štràmac, kao što je u Jasenicama, Popovićima i u Lovincu. U govorima je sinjskoga područja također notirano štramac, a tako je i u Siveriću.

Specifično je što Svetojurci za ‘čvarak' kažu ùcvirak. U tome je značenju u Popovićima ovjereno žmära. Žmara dolazi i u sinjskome kraju te u govoru Siverića.

Sveti Juraj ima leksem gröb, dakle bez poznate mijene ro $>$ re. Grëb je registriran u Ninu, Popovićima i Jasenicama, a ista se varijanta govori u Siveriću i na sinjskome prostoru.

U Svetome se Jurju govori košùnel u značenju 'jastuk', dok u Ninu, Jasenicama i Popovićima kažu kùšinn, kao što je to u Siveriću i na sinjskome području.

Za značenje je 'prozor' zabilježen leksem pùneštra. U Popovićima dolazi pùnestra i pëndžer/pèndžer. Na sinjskome prostoru čujemo ponistra i pendžer.

Značenje je 'porezni službenik, financ' pokrila imenica finānc, jednako kao u Jasenicama. U Popovićima kažu vinānc. Sinjski kraj poznaje varijante filanac i vilanac.Uobičajen je leksem kòtāl, dakle s očuvanim završnim $l$. Popovići imaju kòtā, a i u govorima je sinjskoga područja evidentirano kota.

Za pregaču se u Svetome Jurju kaže záslon, slično kao u Lovincu koji ima záslun. U Jasenicama je zastupljen lik tràvērsa, u Ninu tràversa, u Popovićima tràvēža i tràvēša, u Siveriću traveža, na sinjskome području traverša i traveša.

Značenje 'cipela' u opserviranome govoru pokriva leksem pòstōl. U Ninu je pòstō, u Siveriću postoli (mn.), na sinjskome području postola, posto i cavata, dok je u Jasenicama zabilježena imenica cìpala.

Sveti Juraj i Popovići imaju vèštīd ('odijelo'), Siverić i sinjski kraj veštit.

Kao u standardnome jeziku i u Svetome je Jurju zabilježen oblik krésta. U Ninu čujemo krëšta, a u Jasenicama i Lovincu üvōr.

Za 'zavjesu' narod kaže störa. U Jasenicama je evidentirano kòltrīna, u Siveriću koltrine (mn.), u sinjskome kraju koltrina.

'Lijevak' u Svetome Jurju nosi naziv tràtū $r$, isto kao u Lovincu. Jeseničani za veći lijevak kažu tràtūr, a za manji pîrja. Pîrija se čuje u Popovićima, pirrja u Ninu, pirja u Siveriću. 


\section{Zaključak}

U članku se, pored najvažnijih fonoloških i morfoloških značajki, osvrće na leksik govora Svetoga Jurja, štokavskoga naselja u podvelebitskome području. Analiza je pokazala da govor obiluje leksemima iz naslijeđenoga, slavenskoga leksičkoga fonda, ali i da je prisutan stanovit broj germanizama, orijentalizama te romanizama, što je očekivano. Osim što su leksemi razvrstani po odabranim semantičkim sferama, ukazalo se i na podudarnosti i razlike između nekih leksema ovjerenih u svetojurskome govoru te u drugim štokavskim govorima. S obzirom na činjenicu da je leksik najfluidnija jezična razina, odnosno da je veoma propusna za unos inojezičnih elemenata, bilo je važno terenski prikupiti i proučiti današnju leksičku građu koja blijedi pod nanosima novoga vremena.

\section{Izvori i literatura}

Ivan BUCIĆ, Rječnik govora sela Jasenica, Zadar, 2016.

Ankica ČILAŠ ŠIMPRAGA, Govor Krivoga Puta kod Senja, Fluminensia, 19/1, Rijeka, 2007, 57-74.

Ankica ČILAŠ ŠIMPRAGA, Ikavski štokavski govori između rijeke Krke i Neretve, u: Anita Celinić, Ivana Kurtović Budja, Ankica Čilaš Šimpraga, Željko Jozić, Prinosi hrvatskoj dijalektnoj fonologiji, Split - Zagreb, 2010, 159-224.

Milan DRAGIČEVIĆ, O današnjem ikavskom govoru u Krasnom Polju, Fluminensia, 2/1-2, Rijeka, 1990, 96-102.

Božidar FINKA, Čakavsko narječje, Čakavska rič, 1/1, Split, 1971, 11-71.

Božidar FINKA, Prigodna razmišljanja o međudijalekatskim dodirima i prožimanjima, Hrvatski dijalektološki zbornik, 10, Zagreb, 1997, 129-133.

Filip GALOVIĆ, Dijalektološke zamjedbe o mjesnome govoru Slatina na otoku Čiovu, Ethnologica Dalmatica 25/1, Split, 2018, 137-145.

Filip GALOVIĆ, Govor Donjega Humca, Jezikoslovlje, 15/2-3, Osijek, 2014, 231-267. Filip GALOVIĆ, Govori otoka Šolte, Zagreb, 2019.

Filip GALOVIĆ, O govoru starijih Splićana, u: Dunja Jutronić, Spliske riči. Rječnik: hrvatski standardni jezik - splitski govor, Split, 2018, 13-25.

Mile JAPUNČIĆ, Lovinac jučer, danas, sutra, Zagreb, 2016.

Joško KONTIĆ i slušatelji Hit radija, Sinjanje. Riči Sinja i Cetinske krajine, Sinj, 2014. Josip LISAC, Hrvatska dijalektologija 1: Hrvatski dijalekti i govori štokavskog narječja i hrvatski govori torlačkog narječja, Zagreb, 2003.

Josip LISAC, Hrvatska dijalektologija 2: Čakavsko narječje, Zagreb, 2009.

Iva LUKEŽIĆ, Čakavsko u štokavskome govoru Imotske krajine, Čakavska rič, Split, 31/1-2, 2003, 5-25.

Iva LUKEŽIĆ - Sanja ZUBČIĆ, Grobnički govor XX. stoljeća, Čavle, 2007. 
Ljubomir MAŠTROVIĆ, Ninski govor, Radovi Institituta JAZU u Zadru 2, 1955, 87-140.

Ljubomir MAŠTROVIĆ, Rječničko blago ninskoga govora, Radovi Institituta JAZU u Zadru 3, 1957, 423-465.

Milan MOGUŠ, Današnji senjski govor, Senjski zbornik, 2, Senj, 1966, 5-152.

Milan MOGUŠ, Pogled na današnji jurjevački govor, Filologija, 8, Zagreb, 1978, 227-232.

Milan MOGUŠ, Senjski rječnik, Zagreb - Senj, 2002.

Petar SKOK, Etimologijski rječnik hrvatskoga ili srpskoga jezika I-IV, Zagreb, 19711974.

Josip ŠIKLIĆ, Rječnik govora mjesta Siverić, Siverić 10/1, 2010, 4-22. (Dostupno na: https://www.franjevci-split.hr/pdf/SIVERICpdf.pdf (2019-11-6))

Nikola TOKIĆ - Ivan MAGAS̆, Rječnik sela Popovića, Zadar, 2018.

\section{ABOUT THE LEXIS OF THE DIALECT OF SVETI JURAJ}

\section{Summary}

The dialect of Sveti Juraj is a Shtokavian dialect and belongs to the western dialect, just as all the dialects of the sub-Velebit region, except for the Chakavian dialect of the town of Senj. Senj's dialect is, like the dialect of the administrative and cultural centre of this area, had a certain influence on the dialect of Sveti Juraj, and so even today there are some Chakavian elements in it. In the paper, the most important phonological and morphological traits of the dialect of Sveti Juraj are represented and the lexis of this Shtokavian dialect is especially considered.

Keywords: Sveti Juraj, dialectical features, lexis, new Shtokavian Ikavian dialect, Shtokavian dialect 